\title{
COFFEE TOURISM DEVELOPMENT STRATEGY BASED ON LOCAL CULTURE AS AN EFFORT TO INCREASE INCOME DURING THE COVID 19 PANDEMIC IN ACEH CENTRAL REGENCY
}

\author{
${ }^{1 *}$ Dy Ilham Satria, ${ }^{2}$ Muhammad Yusra, ${ }^{3}$ Hilmi \\ 1,2,3 Faculty of Economics and Business Universitas Malikussaleh \\ *Correspondence Author : dyilham@unimal.ac.id
}

\begin{abstract}
There are so many potential of Gayo highlands tourism, Central Aceh Regency, both natural tourism and cultural tourism. Based on initial observations from data from the Department of Culture, Tourism, Youth and Sports of Central Aceh Regency in 2018 with a total of 38 natural and artificial tourist objects, besides that the Gayo community has customs, culture and traditions that can become one of the cultural tourism destinations, as well as the potential for coffee plantations. For this reason, a more systematic study of tourism development management is needed by combining elements of existing physical and non-physical potential in order to increase the level of community income through the potential arising from tourism activities. The purpose of this study is to further examine the strategy of developing coffee tourism, both in the form of physical elements and non-physical elements through existing local wisdom as an effort to increase income, especially during the Covid19 Pandemic Period in Central Aceh Regency. The research method is descriptive qualitative with a sample of 40 respondents from coffee entrepreneurs and coffee shops in several tourist attraction areas. The results showed that Central Aceh Regency has great potential for the development of a coffee tourism model based on local culture in order to increase people's income, especially people who are directly involved in tourism management and coffee farmers.
\end{abstract}

Keywords: Coffee Tourism, Physical and Non-Physical Elements, Local Culture, Income.

\section{INTRODUCTION}

In the era of regional autonomy, the tourism sector plays an important role in supporting the economy of a region because it has linkages as a source of accelerating regional economic growth. The development of tourism based on local resources will have a double effect on other economic sectors by increasing added value and increasing people's income. Increasing the intensity of the use of labor in tourism development is not only expected to increase people's income, but also be able to create job opportunities and reduce poverty levels (M. Arief Anwar, et al, 2018).

The application of the concept of sustainable development in the tourism sector is known as the concept of sustainable tourism development (Sustainable Tourism Development). First, ecological sustainability, namely sustainable ecology, namely tourism development does not cause negative effects on the local ecosystem. Second, social adaptability, socially acceptable, refers to the ability of local residents to absorb tourism businesses (industry and tourists) without causing social conflict. Third, cultural suitability, culturally acceptable in this context assumes that the impact of the presence of tourists to a tourist destination does not have a negative impact on the development of local culture,

The development of coffee tourism must pay attention to the ability and level of acceptance of the local community which will be developed into a tourist village. This is intended to determine the 
Coffee Tourism Development Strategy Based On Local Culture As An Effort To Increase Income During The Covid 19 Pandemic In Aceh Central Regency

DOI: $10.54443 /$ ijerlas.v1i2.88

character and abilities of the community that can be utilized in the development of tourist villages, determine the type and level of community empowerment appropriately. To determine public acceptance of coffee tourism development activities: 1) Does not conflict with the cultural customs of the local community; 2) Physical development proposed to improve the quality of the village environment; 3) pay attention to the elements of locality and authenticity; 4) Empowering village communities; 5) Pay attention to the carrying capacity and capacity of an environmentally sound (Umi, 2017).

The coffee tourism development strategy based on local culture refers to the physical and nonphysical potential contained in the coffee tourism area to be developed, this is related to the uniqueness of the coffee tourism area in selling its potential to be used as the basic capital as a tourist village. According to Neneg, et al (2018), the development of coffee tourism based on local culture is an activity that is not easy to do if it is not supported by all components of the community in the village. An example is the potential of existing local culture such as coffee harvesting activities that begin using a certain ceremony, this will not become a potential for local culture if it is only done incidentally by each individual land owner.

Central Aceh (Gayo) is one of the most popular tourist destinations in Aceh. The tourism potential of the Gayo highlands has not yet fully developed and developed the local community's economy. The lack of infrastructure funds in developing tourism potential is one of the reasons for tourism in Central Aceh Regency such as roads in place and there is no development. In addition, public concern for the environment and maintaining the comfort and tranquility of everyone who comes to tourism still needs to be improved. Central Aceh Regency has arts and culture such as Didong Gayo, Guel dance which is often performed at weddings and when picking up special guests, the community also has unique socio-cultural activities. Based on the initial observations, the researchers looked at the data from the Department of Culture, Tourism, Youth and Sports of Central Aceh Regency in 2018 with a total of 38 natural and artificial tourist objects. This shows that natural tourism and artificial tourism are superior to cultural tourism.

Even though the Gayo ethnic community has customs, culture and traditions that should be able to become one of the cultural tourism destinations in Central Aceh Regency. Not to mention the potential for coffee plantations and the cultural tradition of drinking coffee that is so thick with the Gayo community that it has a special slogan "Gere ara Kupi Gere ara Cerite" which means no coffee, no story, lots of coffee, many stories (Iwan, 2018). For this reason, an in-depth study of the management of tourism development is more systematic by combining elements of existing physical and non-physical potentials in order to increase the level of community income through the potential arising from coffee tourism activities, by maximizing all the potential of local culture that has not been fully utilized. by the community around tourist sites in Central Aceh Regency.

For that we need an in-depth study of the coffee tourism development strategy, both in the form of physical elements and non-physical elements through local culture that exists in Central Aceh as an effort to increase income, especially during the Covid-19 Pandemic Period. Based on the above phenomenon, the purpose of this study is to measure and analyze the coffee tourism development strategy, both in the form of physical and non-physical elements through local culture in an effort to increase income, especially during the Covid 19 pandemic.

\section{IMPLEMENTATION METHOD}

The stages in this research can be described as; (1) Research preparation, (2) Initial observations, (3) Problem identification and formulation, (4) Activity objectives, (5) Literature and field studies, (6) Data collection, (7) Data processing, (8) Analysis results and evaluation. This research is a field study by conducting direct observations and sourced from primary data and secondary data obtained in the field related to local culture-based coffee tourism located in tourist objects such as coffee plantations and coffee shops, as well as coffee outlets in all tourist attractions in Indonesia. Central Aceh District. The research sample was determined purposively, by taking 40 respondents in each tourism location, totaling 40 coffee shops/coffee outlets. 
The flow of the research model through the analysis of the community profile of coffee business actors around the location of the wiata, the profile of access and control of activities developed in coffee tourism, analysis of the factors causing the decline in income; program analysis is oriented towards increasing income through physical and non-physical potential in the development of kopikopi tourism based on local culture, developing models, reviewing, revising, testing, analyzing, revising, and implementing models. The coffee tourism development model based on local culture as an effort to increase income is constrained due to limited access, lack of knowledge and skills. Further development is needed to realize community independence, especially increasing the involvement and active participation of the community in various income-generating activities. The conceptual framework of the research used is illustrated in Figure 1 below:

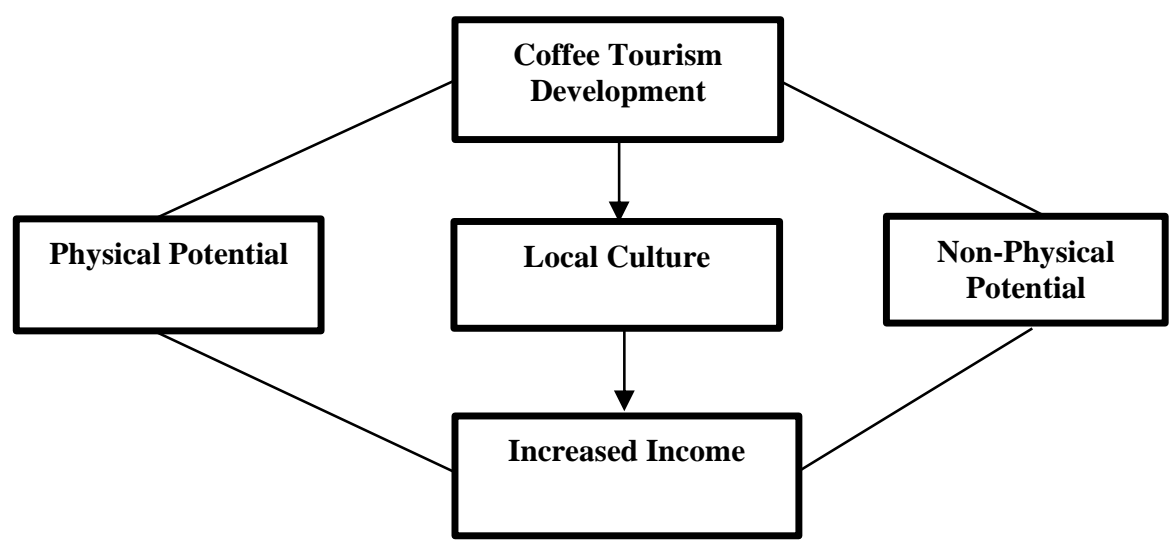

Figure 1 conceptual framework

The social situation in this study takes place in coffee plantations, coffee shops and coffee outlets in tourist attractions in Central Aceh Regency. Business actors who run their business as coffee tourism objects with the theme of coffee plantations, coffee shop business actors by highlighting local culture, and coffee shops business actors around tourist sites that carry out activities consistently and continuously. The research approach method used in this study is a qualitative descriptive method in the form of a case study. The unit of analysis/population to be studied in this study is the location of the coffee tourism object with the nuances of local culture spread in the tourist area in Central Aceh Regency, totaling 40 coffee shops/coffee outlets/coffee cars.

Data collection techniques in this study were obtained from field observations, direct interviews, Fucos Group Discussion (FGD), and analysis of report documents. Finance of coffee businessman in Central Aceh Regency (Sekaran, 2009: 32). Furthermore, information analysis is carried out through several stages, namely; data collection, data reduction and relevant data categories, data display in the form of narratives and matrices, and drawing conclusions and data verification that includes all important information from the answers to existing research problems.

\section{RESULTS AND DISCUSSION}

\subsection{RESEARCH DESCRIPTION}

Central Aceh district has 14 sub-districts consisting of 295 villages. Some of the attractions in Central Aceh Regency are : Lake Laut Tawar, Pantan Terong (scenic attraction), Linge Isak Buru Park (hunting), Loyang Koro Cave, Puteri Pukes, Loyang Datu, Burni Klieten (hiking), Gayo 
Coffee Tourism Development Strategy Based On Local Culture As An Effort To Increase Income During The Covid 19 Pandemic In Aceh Central Regency

DOI: $10.54443 /$ ijerlas.v1i2.88

Waterpark (family tour) and Krueng Peusangan rafting. Didong is one of the original arts originating from this highland area. A group of people sitting cross-legged formingcircle. One of the Ceh (Singer) will sing the poems in Gayo language and the other members will accompany with clapping of hands and clapping of small pillows in a harmonious rhythm. The people of Central Aceh have an annual tradition at the time of the celebration of the proclamation of Indonesia, namely pacuhorsetraditional. The unique thing about this traditional horse race is that the jockeys are young, aged between 10-16 years. In addition, jockeys also do not use a saddle and starting in 2011, Horse Racing is held two times a year, in August during the celebration of the Proclamation of Indonesian Independence day, and in February to commemorate the anniversary of the Takengon Regency which falls on February 17 every year.

Most of the people of Central Aceh Regency work as farmers. Central Aceh Regency produces one of the types ofarabica coffeethe best in the world with a land area of 48,300 hectares, with an average production per hectare of 720 kilograms. Important commodities other thancoffeeissugarcanewith an area of 8,000 hectares, andcocoacovering an area of 2,322 hectares, then there are also plantsvegetablevegetables andpalawija. Most of the population comes fromGayo tribe. In addition there are also other tribes, such as Acehnese, Javanese ethnic, Minang tribe, Batak tribe, Chinese. Ninety nine percent of the people of Central Aceh are Moslem. In general, the society, known from their very nature against all forms of colonialism. This area used to be known as an area that strongly opposed Dutch colonial rule. Gayo people are strong adherents of Islam.

\subsection{DESCRIPTION OF INCOME ON THE RESEARCH SAMPLE}

Based on the results of surveys and interviews with owners of coffee shops, coffee cars, around tourist attractions in Central Aceh Regency, they are classified into 10 main areas consisting of 40 coffee shops/coffee cars that have survived during the Covid19 pandemic, can be seen in table 1 . The following:

Table 1. Income Before and During the Covid 19 Pandemic

\begin{tabular}{cllrr}
\hline No & \multicolumn{1}{c}{ Research Sample } & $\begin{array}{c}\text { Tourist Attraction } \\
\text { Area }\end{array}$ & $\begin{array}{c}\text { Income Before } \\
\text { Pandemic/Day (Rp) }\end{array}$ & $\begin{array}{c}\text { Income During } \\
\text { Pandemic/Day (Rp) }\end{array}$ \\
\hline 1 & Konadi Kopi (car) & Around the Mosque & $1,000,000$ & 500,000 \\
2 & Black Beans & Ruhama (1) & $2,000,000$ & 850,000 \\
3 & Gayowan Kopi (car) & $1,000,000$ & 300,000 \\
4 & AA Coffee (car) & Around Pantan & $1,800,000$ & 900,000 \\
\hline 5 & Keniko Coffee and Souvenir & Terong (2) & 500,000 & 300,000 \\
6 & Keniko Kopi (car) & & 300,000 & $2,100,000$ \\
7 & Bur Rintis & Around Takengon & $2,000,000$ & $1,000,000$ \\
8 & Coffee Taruken & Downtown (3) & $1,000,000$ & 200,000 \\
9 & Horas Coffee & & $1,000,000$ & 300,000 \\
10 & Kopi Kopian (car) & 700,000 & 700,000 \\
11 & Datu Coffee & $4,000,000$ & $1,000,000$ \\
12 & Sintep Kopi (car) & 600,000 & 100,000 \\
13 & Coffee Joints & $1,200,000$ & $3,000,000$ \\
14 & Anggi Kopi (car) & 400,000 & 60,000 \\
15 & Black White Coffee Gayo Arabica & 700,000 & 300,000 \\
16 & Coffe & & $4,000,000$ \\
17 & Explore Coffee & & $1,400,000$ \\
18 & Merabata Coffee & & 600,000 \\
19 & Bumi Aceh Coffee & & 900,000 \\
20 & Platinum Coffee Bar & & $3,000,000$ & 200,000 \\
21 & Time Ruang Kopi & & $1,000,000$ & $2,000,000$ \\
22 & Keni Gayo Coffee & 700,000 & 300,000 \\
23 & Premium Blended Coffee & $1,000,000$ & 300,000 \\
24 & ARB Coffee Shop & $1,000,000$ & 800,000 \\
\hline 25 & Coffee Redines (car) & $1,000,000$ & 200,000 \\
26 & Mendele Bay Caffe & $2,000,000$ & 500,000 \\
27 & Tujuh Semeja Coffee & 800,000 & $1,000,000$ \\
& & & $2,000,000$ &
\end{tabular}




\begin{tabular}{|c|c|c|c|c|}
\hline 28 & Mentari coffee & & $1,200,000$ & 300,000 \\
\hline 29 & Keben Kopi & & 200,000 & 30,000 \\
\hline 30 & Galery Kopi Indonesia & Around Kayu Kul & $9,000,000$ & $1,000,000$ \\
\hline 31 & Jasa Rosting Hawai Kopi & (5) & $1,000,000$ & 500,000 \\
\hline 32 & Master Coffee & & 500,000 & 100,000 \\
\hline 33 & Bur Telege Coffee & Around Bur Telege & 500,000 & 100,000 \\
\hline 34 & Affandi Gayo & $(6)$ & 600,000 & 100,000 \\
\hline 35 & Bismillah Coffee (car) & Around Pantai & 120,000 & 20,000 \\
\hline 36 & Dermaga Pante Menye Bintang & Menye (7) & 210,000 & 90,000 \\
\hline 37 & Star Rafting Coffee & Lukup Badak (8) & 300,000 & 150,000 \\
\hline 38 & Agung Kopi (car) & $\begin{array}{l}\text { Around Mount } \\
\text { Singga Mata (9) }\end{array}$ & 700,000 & 350,000 \\
\hline 39 & Aman Kuba Coffe & Around Bebesen & $4,500,000$ & $2,500,000$ \\
\hline 40 & $\begin{array}{l}\text { G-One Kopi Roastery Pusat Oleh- } \\
\text { Oleh Kopi Gayo }\end{array}$ & Village (10) & $2,700,000$ & $1,800,000$ \\
\hline
\end{tabular}

Source : Observation, Interview, Focus Group Discussion 2021

\subsection{AREA POTENTIAL IN PHYSICAL POTENTIAL}

Physical Potential is divided into 10 (ten) coffee tourism areas spread across the Central Aceh Regency. The physical potential described is the physical potential that is able to support the development of coffee tourism, including beautiful natural scenery, the existence of good road access to tourist villages, and the existence of various natural tourism objects in each Coffee tourism, described as follows:

\section{Around the Ruhama Mosque in Takengon Downtown}

Around the Ruhama Mosque in Takengon, there are four coffee shops, both outlets and coffee cars, which the researchers used as respondents, namely the Konadi Mobil Coffee shop, Black Beans warkop, Gayowan Kopi car, and the AA Kopi Car. The location is located right in the middle of Takengon downtown, Nature in Takengon generally has a cold climate which is an attraction around the Ruhama mosque, there is also a city park that is made very attractive, so it can be a relaxing place for families and young people. Besides that, because it is right around the mosque, when it is time for prayer, you can go directly to the mosque.

\section{About Pantan Terong Tourist Locations}

Around the Pantan Terong tourist location, there are four coffee shops, there are Keniko Coffee and Souvenirs, Keniko Kopi Mobil, Bur Rintis Kopi, and Taruken Kopi. Physically, Pantan Terong can be said is a must tour when coming to Takengon. Pantan Terong peak is at an altitude of 1800 masl, offering views of the entire town of Takengon and the lake. The location is about four Kilo meters from the downtown. if you want to peak enjoy the view and coffee. In addition to a place to drink coffee, this place also presents a beautiful place for photo objects.

\section{Around Takengon Dowtown}

Around the downtown of Takengon, is the location where there are the most coffee shops, here there are 15 (fifteen) populer coffee shops that are the object of research, both shops located in shops, and cars, including Horas Coffee, Mobil Kopian Coffee, Datu Coffee, Sintep Kopi Mobil, Joint Coffee, Anggy Kopi Mobil, Black and White Coffee Gayo Arabica, Lakun Kopi, Explore Coffee, Merabata Coffe, Bumi Aceh Kopi, Platinum Coffee Bar, Coffee Room Time, Keni Gayo Kopi, Premium Coffee Blended, and ARB Coffee Shop.The location is in the center of the town, close to the Inpres market, close to traditional markets, also close to hotels and inns where tourists stay overnight, and also in the middle of the Inpress Market. in the Central Aceh region, the climate is cold, because it is located in an altitude of about 1000-2000 masl, it is among clothing sellers, so when tourists or local residents are tired of shopping for clothes, they can take a break and drink coffee in this area. Also close to the bus terminal. which serves all routes from Aceh and Outside Aceh, there are stalls here that only focus on selling coffee beans and powder, but there are also places to drink coffee. so this location is very suitable for tourists who want a city atmosphere and close to Lake Lut Tawar, also close to the center of typical Gayo souvenirs. 
Coffee Tourism Development Strategy Based On Local Culture As An Effort To Increase Income During The Covid 19 Pandemic In Aceh Central Regency

DOI: $10.54443 /$ ijerlas.v1i2.88

\section{Around Lake Lut Tawar Takengon Region}

Around Lake Lut Tawar, there are five popular coffee shops and coffee cars, namely: Redines Kopi Mobil, Teluk Mendale Caffe, Tujuh Semeja Coffee, Mentari coffee, and Keben Kopi. The location of tourism in this area is about 3-5 KM from the city, the attraction around this location is the direct view of the lake, it is clearly visible, some are even right on the edge of the freshwater lake. The climate is cold, because it is located at an altitude of about 1000-2000 masl. There is also the location of this shop on a hill, so tourists who want to run in the afternoon or bike can stop for a cup of coffee. In addition, there are fauna that usually look like horses, buffalo, eagles, and depik fish typical of Lake Lut Tawar, with the flora around this hill are pine trees that thrive.

\section{Around Kayu Kul}

Around the Kayu Kul area, Pegasing sub-district, Central Aceh district, there are three coffee shops that are popular and are visited by many tourists, namely; Indonesian Coffee Gallery, Hawaii Coffee Roasting Services, Master Coffee.Located about $4 \mathrm{Km}$ from Takengon City, the Indonesian Coffee Gallery is one of the tourist spots for coffee in the middle of a coffee plantation. It is about 5.2 Kilometer from the downtown. In addition, in this area, visitors can buy pineapple and eat pineapple on the spot, because it is a pineapple producing area, so there are a lot of pineapple sellers, this area is also famous for its sweet pineapple. located in an area with an altitude of about 10002000 meter above sea level. With flora in the form of pine trees and coffee trees, and fauna in the form of various types of birds.

\section{Around Bur Telege}

There are 2 coffee shops in the Bur Telege area, namely Bur Telege Kopi and Affandi Gayo Kopi. Bur telege is a tour in the form of a hill, and is decorated with various ornaments. When we are in the center of Takengon we will see the words Gayo Highland on this hill. All tourists will definitely visit this bur telege. The distance from the city is only about $1 \mathrm{KM}$, in the Central Aceh region the climate is cold, because it is located in an altitude area of about 1000-2000 m above sea level. Pine flora and coffee plantations, and fauna in the form of birds are abundant here.

\section{Around Pantai Menye}

Around Mene Beach Bintang District, there are two coffee shops, namely; Bismillah, Kopi Mobil, and Pante Mene Bintang Pier. It is about 19 KM from downtown Takengon. To go to the location we will be served along the way we go through the lake. In the Central Aceh region, the climate is cold, because it is located at an altitude of about 100-2000 masl.Visitors are allowed to bathe around the lake. The uniqueness and charm offered is the pier in the form of an openwork Gayo motif, very beautiful when photographed. This wharf is owned by the "Sadar Wisata" sub-district Bintang District Central Aceh.

\section{Around Lukup Badak}

Star Rafting Coffee Rafting - Lukup Badak. The location of the coffee shop is in the tourist location of Rafting Lukup Badak, Pegasing sub-distric, Central Aceh District. It is $8.8 \mathrm{Km}$ from downtown. The uniqueness of this coffee shop is that you can play as well as rafting with family and friends. The location of this coffee shop is not too far from the Pineapple Kayu Kul tour, even in one sub-district. Tourists usually after rafting will stop by to taste pineapple, either to eat on the spot or take it home. In the Central Aceh region, the climate is cold, because it is located at an altitude of about 100-2000 meters above sea level.

\section{Around Singah Mata Mount}

Agung Kopi Mobil around Singah Mata tourism, is the only coffee car that has survived during the Covid19 pandemic. The tourist location is in Mount Singah Mata, about 4 KM from the city center of Takengon. If tourists from the Banda Aceh area, Bireuen will find this location first before the city center of Takengon. The charm offered is a relaxing coffee drink with a view of the entire city of Takengon and the lake which is a shame if you miss it. The cold climate is perfect for drinking a cup of coffee in this place. This location is also right beside the Takengon - Bireuen highway which is surrounded by pine trees. 


\section{Around Kp. Bebesen (Filigree Craft Village)}

There are two coffee shops, namely Aman Cuba Coffee, and G-One Kopi, Aman Cuba is arguably the oldest souvenir center in Takengon, and has been managed for generations. Specialty souvenirs are coffee beans and coffee grounds, Aman Cuba is located in the city, precisely in Simpang.Lemah. The uniqueness is that we can see how coffee beans/powder are processed directly, even this location is often used as a location for learning coffee for school children. This location is close to hotels that are usually used as places for tourists to stay. Meanwhile, G-One Kopi is also a souvenir center for specialty coffee beans and coffee grounds with various types of coffee. The uniqueness of this warkop is that it sells many types of gayo coffee such as Arabica, Bergendal and so on.

\subsection{THE POTENTIAL OF THE REGION IN THE FORM OF NON PHYSICAL}

The non-physical potential in the form of the characteristics of respondents involved in coffee tourism development activities can be described as follows

\section{Characteristics of Respondents by Age}

The age of respondents around coffee tourism locations in Central Aceh Regency includes various age groups. This shows that the opportunities for involvement in tourism development can be for various age groups. The average age of respondents is in the range of 25-35 years, the age of the highest respondent is 54 years, and the age of the lowest respondent is 18 years.

\section{Characteristics of Respondents by Education}

According to education, respondents around coffee tourism locations in Central Aceh Regency are dominated by high school graduates, namely 23 people, while 17 people have a bachelor's degree. The difference in the education level of the respondents will certainly affect the management and development of tourist villages, which is assumed that with the higher the education level of the respondents, the management and development of coffee tourism will be better.

\section{Respondent's main livelihood}

The main livelihoods of respondents around coffee tourism locations in Central Aceh Regency are the majority of coffee entrepreneurs and farmers

\section{Income from Coffee Shops/Outlets/Cars during Normal Situations.}

Income from Coffee Shops/Outlets/Cars during Normal Situations on average is Rp. 1,580,750,/day, for the highest income is Rp. 9,000,000,-/day, while the lowest income is Rp. 120.000,-/day, this is largely determined by the size of the existing coffee shop/outlet/car coffee, and also determined by the product.

\section{Income from Coffee Shops/Outlets/Cars during the Covid19 Pandemic}

The average income from Coffee Shops/Outlets/Cars during the Covid19 Pandemic is Rp. $7,275,000,-/$ day, for the highest income is Rp. 4,000,000,-/day, while the lowest income is Rp. 20,000 , -/day, some even reached Rp. 0 ,- or no income at all. The average income during the COVID19 pandemic dropped dramatically to $10 \%-40 \%$ of normal income.

\subsection{Coffee Tourism Development Strategy based on Local Culture during the Covid19 Period}

According to Lubis, et al (2020) the coffee tourism development strategy based on local culture refers to the physical and non-physical potential contained in each coffee tourism area to be developed, this is related to the uniqueness of the coffee tourism area in selling its potential to be used as a potential base capital. tourist. An example is the potential of existing local culture such as coffee harvesting activities that begin using certain ceremonies, processions of prayer together and dances, and closed with a meal together. This will not be a potential local culture if it is only done incidentally by each individual coffee land owner. The potential that should appear on the surface as a cultural activity is not visible because it is not carried out communally and is only private.

According to Maria (2016), a coffee tourism development strategy based on local culture needs to pay attention to the following: 1) Marketing of coffee tourism packages that show the selling value 
Coffee Tourism Development Strategy Based On Local Culture As An Effort To Increase Income During The Covid 19 Pandemic In Aceh Central Regency

DOI: $10.54443 /$ ijerlas.v1i2.88

of tourism. 2) Management of sustainable coffee tourism and preserving coffee tourism itself. 3) Community empowerment of coffee tourism business actors and the community around the coffee tourism object itself as part of the coffee tourism potential. 4) Coffee tourism that is not monotonous so that it does not give the impression of being ordinary to tourists. 5) Avoiding conflicts of interest between adjacent coffee tourism business actors. 6) Can improve the economy, especially the income of the coffee tourism business community.

Socio-cultural potential that will be developed as local culture can become a barrier for coffee tourism in its development if it is not approached properly, for example if the community in coffee tourism is a heterogeneous community, groups based on religion, race, family tree, economic status can arise and others. However, if there is a good enough approach, this heterogeneity can be used as a profitable potential for the development of tourist villages (Khoirani, 2017).

Conflicts of interest can occur because of mutual struggles in tourism management, both between village officials, the community, and third parties. This should not happen because it is very unprofitable for the development of tourist villages. Empowerment of local communities aimed at improving welfare or improving the economy will not be achieved in the presence of such conflicts of interest. Empowerment is the active role of the community that is required to advance or not coffee tourism. The active role here is in preparing to receive and serve guests/tourists who visit with the uniqueness that will be served to them. The active role of the community is also needed in the development of sustainable coffee tourism and the preservation of natural resources that exist in coffee tourism.

Efforts to increase income made by the community, especially coffee tourism entrepreneurs during the Covid19 pandemic, are by marketing their products through online media, and special ordering methods for take away (take away) during the implementation of Level 3 and 4 Community Activity Restrictions (PPKM) in Aceh Regency. Middle. In addition, there are also those who open a side business by selling basic necessities, and some even switch professions to become coffee farmers.

\subsection{Local Culture-based Coffee Tourism Development Model}

Based on the analysis of the potential of the region, both physical and non-physical potential, as well as an analysis of tourism activities and local culture, a model for the development of coffee tourism in Central Aceh Regency can be made in almost all regions that have the potential and are very supportive for coffee tourism, with local culture in the form of physical and non-physical potential that very diverse. The distance from Takengon city to the coffee tourism object is very diverse, from the distance of only 5 minutes to 45 minutes, with fairly good road access. The cool climate with panoramic views of the mountains and freshwater lakes makes Central Aceh Regency have great potential in world coffee tourism. It's just that, in the current state of the pandemic, it takes extra effort to boost income.

\section{CONCLUSION}

Based on the potential of the region, both physical and non-physical potential as well as coffee tourism activities and local culture in the research area, a model for developing coffee tourism in the entire coffee tourism area in Central Aceh Regency can be used as a model for developing coffee tourism with natural and cultural tourism to increase people's income in the region. the time of the covid-19 pandemic. As an effort to increase the income made by the community, especially coffee tourism entrepreneurs during the Covid19 pandemic, by marketing their products through online media, and special ordering methods for take away during the implementation of the Implementation of Community Activity Restrictions (PPKM) Levels 3 and 4 in the Regency. Central Aceh. In addition, there are also those who open a side business by selling basic necessities. 


\section{REFERENCES}

Ansir launtu, Chaerunnisa Rumianti, Patta Rapanna. 2018. The Development of Tourism Based on Local Wisdom in Indonesia. International Journal of Innovative Science and Research Technology. Vol. 3, Issue 3.

Arief Saleh Sjamsu, I Made Krisna Adhi Dahrma. Feasibility Study of Coffee Tourism Development Potential in the Saponda Island Region in Konawe Regency. National Seminar on Applied Technology Based on Local Wisdom. ISSBN : 978-602-71928-1-2.

Iwan Bicer, Eddy Gunawan. 2018. The Effect of Tourist Visits on Economic Growth in Central Aceh Regency. Student Scientific Journal (JIM). Vol. 3, No.3, 370 - 378.

Khaironi, Etty Soesilowati \& Thriwaty Arsal. 2017. Local Wisdom of the Gayo Ethnic Society as a Cultural Tourism Destination in Takengon City. Journal of Educational Social Studies. Vol. 6 No. 3, 99 - 11.

Lubis, Hisnuddin, Nely Rohmatillah, Dania Rahmatina. 2020. Strategy Of Tourism Village Development Based On Local Wisdom. Vol. 9, No. 2.

Maria CB Manteiro. 2016. Coffee Tourism Development Model Based on Local Wisdom as a Poverty Reduction Strategy in Rote Ndao Regency, East Nusa Tenggara. Journal of Business \& Management. Vol. 2, No. 2.

Neneng Komariah, Encang Saepudin, Pawit M. Yusup. 2018. Development of Local Wisdom-Based Coffee Tourism. Enchantment Tourism Journal. Vol. 03 No. 2, 158 - 174.

Now, Uma. 2009. Research Methods For Business, Salemba Empat: jakarta.

Stephanie Chok, Jim Macbeth, Carol Warren. 2007. Tourism as a Tool for Poverty Alleviation: A Critical Analysis of 'Pro-Poor Tourism' and Implications for Sustainability. Current Issues in Tourism. Vol. 10, Nos. $2 \& 3$.

Umi Thoifah Amalia, Endang Purwaningsih. 2017. Local Wisdom Tourism Development Of Semarang With Tourism Cluster System As An Action For Sustainable Economics Development. Education and Language International Conference Proceedings. May, p.871 - 879.

Vincentia Reni Vitasurya. 2016. Local Wisdom for Sustainable Development of Rural Tourism, Case on Kalibiru and Lopati Village, Province of the Special Region of Yogyakarta. Procedia-Social and Behavioral Sciences. 216 (2016) $97-108$. 
Volumes 1 No 2 (2021)

Coffee Tourism Development Strategy Based On Local Culture As An Effort To Increase Income During The Covid 19 Pandemic In Aceh Central Regency

DOI: $10.54443 /$ ijerlas.v1i2.88 